\title{
1 Environmental implications of nitrogen output on horse operations: A review
}

3 Rebecca C. Bott ${ }^{\# 1}$, Elizabeth A. Greene ${ }^{*}$, Nathalie L. Trottier ${ }^{\dagger}$, Carey A. Williams ${ }^{\S}$, Michael L. Westendorf ${ }^{\S}$, 4 Ann M. Swinker ${ }^{+}$, Sara L. Mastellar ${ }^{\#}$ and Krishona L. Martinson*.

$6 \quad$ \#Department of Animal Science, South Dakota State University, Brookings, SD 57007;

7 *Department of Animal and Veterinary Sciences, University of Vermont, Burlington, VT 05405-0148

$8 \quad$ 'Department of Animal Science, Michigan State University, East Lansing, MI 48824;

$9{ }^{\S}$ Department of Animal Sciences, Rutgers, the state University of New Jersey, New Brunswick, NJ 08901;

$10{ }^{+}$Department of Animal Science, Pennsylvania State University, University Park, Pennsylvania

11 Department of Animal Science, University of Minnesota, St. Paul, MN 55108;

$14{ }^{1}$ Corresponding author: Dr. Rebecca C. Bott, Department of Animal Science, South Dakota State University, 15 Brookings, SD 57007, phone: 517-432-5140, fax: 517-432-0190, Rebecca.Bott@sdstate.edu. 
Abstract

Nutrients such as nitrogen, which go unutilized during the digestive process, are then excreted into the environment via urine, gas or fecal matter. Excess nitrogen released in this manner may contribute to a reduction of the quality of air and groundwater sources. Many states have introduced or developed legislation mandating nutrient management plans on livestock operations to reduce environmental nitrogen losses. Strategies for reducing the environmental impacts of nitrogen on equine operations are two fold, including a reduction in nitrogen inputs and better management of nitrogen outputs. The practice of precision feeding, or feeding to accurately meet, but not exceed the nutrients requirements of an animal is a plausible method for reducing nitrogen inputs. This approach is not widely implemented, as feeding protein in excess of requirements is a common practice in the equine industry. Also, precision feeding is predicated on a body of data containing the nutrient availability and digestibility in different feed sources; data which are not fully elucidated in the horse. Management of nitrogen outputs on equine operations is largely based on data extrapolated from other livestock operations as well as a few preliminary efforts on horse farms. The potential impact of equine operations on nitrogen losses is explored in this review, shedding light on areas where further research and management strategies are needed.

Keywords: horse, protein, nitrogen, lysine, digestibility, environment

\subsection{Introduction}

Feeding practices with the goal of precisely meeting the dietary requirement of the first limiting amino acids (AA) have been implemented in many livestock systems to optimize performance and, recently, to minimize nitrogen $(\mathrm{N})$ excretion into the environment, for example the swine industry [1]. Paradoxically, feeding protein in excess of requirement has been a common practice in the horse industry [2]. Fecal and urinary nitrogen from livestock contributes to ground water contamination and decreased environmental air quality [3]. With increasing public awareness and emerging regulations to limit nitrogen losses to the 
41 facilities, especially in increasingly urbanized areas. Strategies to mitigate the impact of equine feeding

42 practices on the environment are contingent on knowledge of factors that impact protein utilization of 43 common feeds for equids. Due to the complexity of the equine digestive tract and the vast difference in feed 44 types, including forages and cereal grains, prediction of feed protein digestibility and nitrogen output 45 remains a challenge [4]. The goals of this review are to provide an overview of the current knowledge on 46 nitrogen utilization in equids in relation to the environment, and to identify knowledge gaps that preclude the 47 progress in designing prediction models of nitrogen excretion in equids. The specific objective of this 48 review is to assess the potential impact of nitrogen excretion from equids on the environment.

\subsection{Environmental implications of excreted nitrogen}

Nitrogen in the feces and urine must be managed to prevent consequences to the environment, such as water contamination and decreased air quality [5]. Excess nitrogen in the air and water will eventually reach larger bodies of water, where it can contribute to the deterioration of fisheries and fish habitats through harmful nutrient loading [6]. Manure nutrients (nitrogen, phosphorus and organic matter) can be major pollutants in lakes and estuaries as well as rivers. Nitrogen attached to eroded soil particles may reach waterways through surface runoff or wind deposition. These waters, rich in nitrogen and other manure nutrients promote a proliferation of plant life, especially algae. This process is called eutrophication [7].

Algae growth and the decomposition of organic matter in water bodies reduces the dissolved oxygen content of the water, which may lead to fish kills, odors and other negative impacts on the aquatic ecosystem [8]. Though the larger environmental concern for nitrogen is surface runoff, nitrogen volatilization as ammonia presents other problems including nonpoint source pollution through rain, and the effects of volatilized ammonia on human health [9]. 
with urinary urea to form ammonia. Urease activity in feces is high; therefore urea is rapidly converted to

ammonia after excretion. It is the physical process of combining urine and feces after deposition on a floor surface, which results in ammonia volatilization in the barn. Ammonia emissions (kg/LU; Livestock Unit $500 \mathrm{~kg}$ live weight) are predicted to be lower in horses than in cattle, pigs, poultry, or sheep [10]; however, ammonia emitted by horses is no less able to impact the environment on a unit-by-unit basis.

Other factors can influence ammonia volatilization in livestock housing. They include temperature, air velocity, $\mathrm{pH}$, surface area, manure moisture content, and storage time. For example, high $\mathrm{pH}$ and temperature favor increased ammonia emissions. Horse manure $\mathrm{pH}$ typically ranges from 7.7 to 8.2 when calculated from soiled stall waste, depending on the bedding source [11]. The $\mathrm{pH}$ of horse manure samples collected between 2007 and 2014 and analyzed at the Pennsylvania State University Ag Analytical Services Laboratory ranged from 6.9 to 8.2 with an average of 7.8 , which allows for fairly rapid emission of ammonia into the atmosphere [12]. Only a few studies have been conducted to calculate the amount of nitrogen and/or ammonia concentration of horse stall waste, however, the amount will depend on a myriad of factors including location, time of exposure and bedding type. Horse stables are noted to have higher ammonia concentrations than pastures. This correlated with higher equine exhaled breath condensate $\mathrm{pH}$ in stables compared to pastures [13]. One study looked at four different bedding types for the purpose of calculating composting rate [11]. The study found that when long straw is used for bedding it has a higher percentage of total nitrogen prior to composting than a pelletized straw and pelletized wood product. However, the amount for long straw was not statistically different than when wood shavings were used for a bedding source. This study also found that ammonia did not decrease after composting and therefore indicating that it was not completely converted to nitrate or that the organic matter was not completely degraded by the composting. Table 1 indicates nitrogen and phosphorus content of feces and different bedding sources from soiled stalls in different studies.

The Environmental Protection Agency considers ammonia a threat to air quality because of contribution to surface water eutrophication, nitrate contamination of ground water and the associated 
impaired air quality [14]. Ammonia contamination has the potential for at least short-term adverse effects on agricultural workers involved in animal care $[15,16]$. Subjects in a study performed to simulate residing in close proximity to a swine operation exhibited headaches, eye irritation, and nausea [16]. In studies of workers at swine concentrated animal feeding operations (CAFOs), $25 \%$ of the workers reported at least one of the following respiratory symptoms; asthma, bronchitis, acute respiratory distress syndrome, and organic dust toxicity syndrome [15]. However, as far as the authors know there has never been a study evaluating the health of equine farm workers who are exposed to high levels of ammonia.

In a study conducted in horses fed at approximately $165 \%$ of the recommended protein amount [17], authors showed that elevating protein levels in a horse's diet increases the ammonia and nitrogen levels excreted in manure, the ammonia in the atmosphere, and the urea nitrogen in the animal's blood. More specifically, fecal $\mathrm{N}$ and ammonia were higher (approximately 35 and $50 \%$ higher, respectively) in the high protein fed horses than in the control fed horses. Nitrogen and ammonia for control horses was $0.242 \pm 0.01$ and $0.034 \pm 0.008$, respectively, while nitrogen and ammonia was $0.278 \pm 0.01 \%$ and $0.068 \pm 0.008 \%$, respectively, for horses fed high protein diets $(\mathrm{P}=0.015)$. When atmospheric ammonia was tested by an 8 hour accumulation via Dräger tube, there was a significantly higher level of ammonia in the air in the stalls of horses fed the high protein diet. The high protein horses averaged $37.8 \pm 3.4 \mathrm{ppm}$ while the control horses averaged $25.4 \pm 3.4 \mathrm{ppm}(\mathrm{P}=0.029)$ [17]. This could also lead to the question of horse health since these Dräger tubes were placed on the noseband of the horses' halters over the course of an 8 hour period while stalled. These levels could potentially be a problem for the horses' health if left exposed for an extended period of time. A study in Japan found that a horse inhaling only 2 to $17 \mathrm{ppm}$ of ammonia (range of ammonia in an enclosed trailer) over the course of 40 hours created excessive nasal discharge and slight swelling of the nasal cilia [18]. This same study found that another horse inhaling 40-130 ppm (maximum exposure for humans) had a much more severe nasal discharge, swelling and irregular distribution of tracheal epithelium and edema of the submucosa, loss of nasal cilia, and more severe swelling than the horse exposed to 2-17 ppm. This study indicates that inhalation of these concentrations of ammonia is detrimental to the 
115 respiratory health of horses. Future research should further investigate the possible negative consequence for 116 long-term exposure to ammonia using larger sample sizes.

117 Another study compared sawdust bedded stalls to paper bedding (recycled phone books) to 118 investigate the ammonia differences and horse health over a 14-day period [19]. Ammonia samples were 119 taken from an air pump placed at horse nose height for a period of 30 seconds and found the ammonia levels 120 were higher with the sawdust bedding $(1.42-2.54 \mathrm{ppm})$ compared the paper bedding $(0.21-0.88 \mathrm{ppm})$.

121 However, horse health variables (e.g. endoscopic examination of the nasal passage and trachea, tracheal 122 wash cytology, tracheal inflammation, and general health observations) did not differ between bedding types. 123 Pratt et al. [20] found that when using straw bedding instead of rubber mats ammonia concentrations rose to 124 a peak of $14 \mathrm{ppm}$ after 14 days in the same stalls; stalls were cleaned each day. This study did not find any 125 respiratory or health complications with horses exposed to this level of ammonia. However, it is possible 126 that diet may effect nutrient excretion in the context of environmental contamination, air quality and horse 127 health. More research is needed to evaluate the effect of different feeding strategies on nutrient excretion in 128 the context of environmental contamination and air quality. is excreted in urine or feces, as it has been estimated that less than $45 \%$ of consumed protein is utilized and 133 made into animal protein [21, 22]. It has been shown that horse owners commonly over feed protein, up to $134150 \%$ of the recommended requirements [2]. In a survey conducted by Harper [23], horse owners fed their 135 horses $161 \%$ of NRC [24] CP requirements on average. Maintenance horses were associated with greater 136 overfeeding than working horses. Maintenance horses require fewer nutrients than working horses [24];

137 however, they often received the same type of concentrate as their working counterparts on any given farm, 138 just in smaller amounts. Those concentrates often have higher concentrations of nutrients than required for 139 maintenance, which leads to excessive nutrient supplementation and therefore nutrient excretion. Usually, 
140 maintenance horses can be sustained on forage only diets [25]. Excess protein in the horse diet is then 141 excreted in sweat, feces, and urine (Figure 1).

142 There are several situations when excessive protein or an imbalance can occur. A forage ration 143 consisting primarily of excellent quality hay typically has excessive levels of protein and soluble protein.

144 Formulating feed rations with higher than required protein levels, to ensure all essential amino acid 145 requirements have been met often compounds the problem. It is possible to meet minimum requirements for 146 crude protein while being deficient in single amino acids [24]. When this occurs, whole body protein 147 synthesis might be limited [26]. Depending on the actual performance level of the horses, this can result in 148 excessive levels of nitrogen being fed and excreted. Furthermore, in many operations a single diet is fed to 149 all horses without consideration of activity levels or physiological states of individual animals. This practice 150 could lead to over- or under-supplementation of individual animals and poor overall nitrogen management.

A few studies have looked at reducing the $\mathrm{CP}$ concentration of horse rations through supplementation 152 of purified limiting amino acids. Lysine added to linseed meal and brewers dried grain diets with hay has 153 increased foal weight gain and feed conversion efficiency [27, 28]. Staniar et al. [29] reduced the CP level 154 of a supplement to $9 \%$ while fortifying with lysine and threonine to growing Thoroughbreds on pasture. For 155 the overall observational period no differences in physical growth measurements were observed in the 156 crystalline amino acid supplemented group (9\% CP) compared to the control (14\% CP).

Feeding excess dietary nitrogen not only is of consequence to the environment, but also to the animal and cost of the diet. There is a metabolic energy cost associated with excreting excess nitrogen in the urine, 159 making diets with excess protein inefficient and not cost effective. Additionally, higher protein diets can 160 affect acid-base balance [30], heat production [31], and water requirements [30]. All of these factors are of 161 particular concern to the athletic horse. 


\subsection{Nitrogen content of common equine feedstuffs}

Digestibility of a protein and absorption of its amino acid constituents are the main determinants of protein quality and the predictor of utilization for maintenance or productive functions by the animal as compared. Domesticated equids are fed a wide variety of feeds ranging from herbage to seeds. The composition of proteins and their availability for digestion vary extensively across feeds, thus rendering prediction of nitrogen excretion difficult.

Nitrogen in equine diets comes from forages, grains and oil seed meals. Legume forages generally have higher CP concentration than grasses, 20\% vs 11 to $13 \% \mathrm{CP}$ DM basis [32]. Within grasses, cool season grasses generally have higher $\mathrm{CP}$ concentration (average of $15 \% \mathrm{CP}$ on an DM basis) than warm season (11\% CP DM basis) [32]. Although the CP concentration of grains does not vary as greatly as that of forages, it can differ between cultivars. Wheat cultivars can range from 13-15\% CP [33]. Oilseed meals have greater CP concentration than grains. Soybean meal, cottonseed meal and linseed meal are about 51,44 and $36 \% \mathrm{CP}$ on a DM basis, respectively [32].

Several factors influence the protein content of plants. Plant maturity plays a role with immature forage plants having greater protein content than more mature plants as reviewed by Pagan [34]. For instance, $\mathrm{CP}$ content of alfalfa decreased from $15 \%$ to $9 \%$ after 20 additional days of growth [35]. Fertilization and management practices additionally influence the nitrogen content of forage with greater amounts in grasses receiving fertilizer and regular clipping [36]. Fertilization can also increase the CP concentration of grains $[37,38]$. Crude protein and nitrate concentration of common horse feeds are outlined in Table 2.

Sources of nitrogen in feedstuffs include protein nitrogen and non-protein nitrogen (NPN) compounds. Stage of maturity may affect the amino acid profile of alfalfa [39], but red clover and grass amino acid profiles may not be as influenced by maturity [40]. Some grain cultivars have altered amino acid characteristics. Breeding for specific characteristics can change the relative proportions of proteins present 
189 in the plant resulting in an altered amino acid profile. One such example is a high fat oat cultivar [41].

190 There are also high lysine corn cultivars that have been specifically developed to improve feed value [42,

$19143]$.

192 One of the most common forms of NPN in plants are nitrates, and much of the nitrogen absorbed

193 from the environment and therefore utilized by plants, is in the form of nitrates. Factors affecting nitrate

194 accumulation in plants including level of nitrogen fertilization, forage species, maturity, herbicides, and light

195 intensity, have been reviewed by Crawford et al. [44] and by Wright and Davison [45]. Some forms of

196 nonprotein nitrogen are commonly added to ruminant diets as reviewed by Huntington [46]. Urea is a type

197 of NPN that is minimally utilized by equids [47-49]. Unlike ruminants, NPN compounds are not added to

198 practical equine diets; because the majority of the microbial population and bacterial protein synthesis is

199 distal to the small intestine, horses are not as efficient at utilizing these forms of nitrogen [50].

200 Selecting feedstuffs containing appropriate protein and nitrogen profiles to meet the horse's dietary

201 needs may help to reduce nitrogen outputs through strategic selection of inputs.

\subsection{Nitrogen balance}

A Whole Farm Nutrient Balance [14] assessment is a tool that can be used to determine generation of excess nutrients on farm and can be useful in developing plans to manage nutrient buildups. This idea may be helpful for reducing nitrogen losses in equine production. The challenge is to manage the animals, crops, and other farm components to efficiently use available manure nitrogen, and reduce potential losses to the environment [51]. Nutrient accumulation occurs when nutrient inputs exceed nutrient outputs [52]. Whole farm balances of inputs and outputs can be used to assess the risk of non-point source pollution and identify pollution reduction strategies [53]. Nutrient balances can be calculated on several levels including regional, whole farm, and field scales [54]. 
Whole farm or "farm gate" nutrient balances compare the nutrients of concern, which come in and go

213 out of the farm gate [55]. Products typically going onto a farm through the gate include purchased hay and

214 grain or concentrates, mineral fertilizer, manure, bedding, and live animals [55]. Products typically leaving a

215 farm through the gate include crops, eggs, milk, meat, fiber, live animals, and manure [55].

A Pennsylvania State University study [23] which followed 14 Mid-Atlantic horse farms for an entire year, found that whole farm balances on Mid-Atlantic horse farms averaged 73\% for nitrogen, which is similar to findings in other species. Kohn [56] reported that whole farm nitrogen balance averaged $66 \%$ on high efficiency dairy farms. Percentage is an indicator [57] of the proportion of nitrogen inputs (feed, fertilizer, animals, and legume nitrogen) not accounted for in the outputs (crops, animal products, and manure). As a point of reference, a lower percent would mean a higher or poorer balance for the farm. On horse farms, there may be a wider range of nitrogen balance values due to the amount of manure horse farms export. In the Pennsylvania State University study [23], horse farms exporting all their manure averaged $39 \%$ balance for nitrogen; and they reported that all farms imported some feed. The mean farm balance for those that did not export any manure was $100 \%$, indicating that all nitrogen imported onto the farm remains on the farm. Determining nitrogen balance will always be more of a challenge on horse farms since there are a variety of types of operations, including breeding, boarding, performance and pleasure, etc. [58] often having a high turnover rate of horses; a Rutgers University study [59] found that an average of only 5 of 13 horses remained on 20 farms sampled after one year (most left the farm, some were removed due to age, disease, physical defect, etc.). Manure that remains on pasture when horses are grazed can be substantial and will also influence balance calculations, and is complicated if rotational pastures are poorly maintained. Finally, the amount of manure exported can either help or hinder a farm's balance depending on the amount exported.

Whole farm nutrient balance is critical for managing nitrogen losses in the environment. As this issue has gained public awareness, several states have developed legislation to manage balance on farms. Depending on the individual state's definitions of "farming", many equine operations are not factored into 
the nutrient balance equation. Many hobby or small farms, which may have high nonpoint source pollution

238

239

potential, may not be accounted for if they do not hit the threshold of "farming" definitions. In New Jersey, any facility with less than eight horses is encouraged, but not required to establish and follow an animal waste management plan [60], while Vermont's new small farm regulations accounts for larger farms, not regulating any farm using less than ten acres, and/or those where farming is not considered a business [61]. It is important to realize that current legislation may help to mitigate some nitrogen losses on targeted operations, though livestock farms including horse farms of any size can have an impact on the environment. Farms with compacted soil, bare patches of pasture or with manure storage located near ground water sources should be managed to mitigate potential environmental impacts [62].

The Netherlands was the first country to research and develop methods to reduce environmental impact of livestock operations. Their programs focused on three solutions 1) reduce nutrient inputs in when fed in excess of requirements, 2) apply practical management solutions to reduce nutrient usage of outputs on farm, and 3) increase manure that is exported off farm [5]. These are all programs that have been previously tested and implemented on many concentrated animal-feeding operations (CAFOs) in the United States [51], and have plausible implications on horse farms. Hauling manure off the property can improve farm balance although neighboring crop farms have to be willing to work with the producer [57]. However, equine research and implementation is much slower to follow. It has been reported that most horse farms in the Chesapeake Bay area export nearly $50 \%$ of their manure $[58,63]$ found that $58 \%$ of New Jersey horse farms disposed of some or all manure off-site while $54 \%$ of survey farms spread some manure on their farms.

\subsection{Challenges to precision feeding nitrogen in the horse industry}

In a Pennsylvania SARE Project Report [64], farm managers reported it was very difficult for horse owners to balance horse rations. Most farms used a commercial mixed feed concentrate that could not be adjusted. However, one farm with 70 horses reported that all horses were on individual diets. Most farms reported feeding hay from different weekly truckloads and did not produce hay on farm. In most cases, farm 
managers are unable to make major feed ration adjustments due to these reasons. Concentrates often include

more $\mathrm{CP}$ than is required to ensure that individual amino acid and CP requirements have been met when the concentrate is fed with a variety of forages with different $\mathrm{CP}$ and amino acid contents. However, caretakers

265 of animal species should be able to incorporate best management practices (BMPs) that help to reduce nitrogen excretion. A major deterrent in reaching a nearly perfect balance is feed cost and profit

267 [51]. However, in the horse industry, the deterrent appears to be management traditions, convenience, and a

commercial or pleasure horse operations. This is an important consideration since most horse farms fall in this category. For example, the average size of horse farms in Minnesota participating in a pasture management program was 10 acres with 5 horses [65].

When attempting to procure a valid figure on equine nitrogen excretion in light of multiple quantities and types of feedstuffs provided at any given equine operation, the most logical places to evaluate or attempt to calculate prediction equations are going to be based on either feed consumed or in fecal nitrogen levels excreted. Zeyner and Kienzle [66] used data from over 250 digestion trials to establish a predictive formula to estimate digestible nutrients in equine feed rations. They were able to confirm a strong uniformity of crude protein, demonstrated through linear regression of digestible crude protein by total consumed crude protein. Utilizing this information and resulting formula calculation $(\mathrm{DCP}=-2.27+0.917 \times \mathrm{CP})$, allows equine nutritionists to calculate a reasonable nitrogen excretion value based upon feed intake of horses on farms. Mesochina et al [67] evaluated in vivo digestibility data from horses fed 27 different forage diets to create prediction equations for crude protein and other dietary parameters for horses grazing on pasture or rangeland. They reported that fecal crude protein and dietary fiber were the best predictors of diet digestibility. However the most accurate estimates of diet digestibility were determined when dietary variables such as dietary crude protein and fiber were included in the calculations. Readers should be cautioned that these approaches may not be reliable predictors in horses that are fed low protein or excessively high protein diets. 


\subsection{Programs and Regulations}

In addition to the myriad of intrinsic reasons for managing horses to minimize nitrogenous impacts on the environment, horse owners, especially in populated areas near watersheds, recognize regulations imposed by government. While all horse farms fall under the jurisdiction of the Federal Animal Feeding Operation (AFO), which is administered and regulated by the Environmental Protection Agency (EPA), many states have begun developing and passing laws which require higher standards than the federal requirements. Most of these recommendations and/or regulations pertain to limiting nonpoint source pollution of state waters and

Waste Management, BMPs, Accepted Agricultural Practices, most contain requirements and limits for direct animal access to waterways, manure storage and/or application, and grazing near wells, neighboring property and state waters. Recently, Vermont passed legislation [61] which extends requirements to small farms. In the past Vermont required permitting for Medium (150-499 horses) and Large (500 or more horses) Farm Operations. This water quality bill includes a certification for Small Farm Operations, which are currently defined as farms "on which 10 or more acres are used for farming", and have no more than 149 horses and the lower limit has yet to be determined by the Secretary of Agriculture, Food, and Markets. While farms falling under these guidelines are required to submit annual certification of compliance, the law extends to any farm, which potentially provides a threat to water quality through potential threat of discharge or contamination of groundwater. In addition, there are sections which will allow for compliance inspection at any time, and require water quality training for eight hours over each five year period on topics including prevention of discharges, mitigation and management of storm water runoff, land application of manure or nutrients, nutrient management planning, and other farm compliance rules and regulations.

Horse farms may pose an environmental risk of nonpoint source pollution since they often have higher stocking rates than can be accommodated by natural methods of nutrient absorption. In 2011, the Pennsylvania Department of Environmental Protection [68] mandated that farms with as few as one animal 
312 fitting the livestock classification (e.g. horse, goat, sheep) must document the adherence to guidelines and

313 submit a farm manure management plan. Maryland has incorporated horse operations, which bring in

$314 \$ 2,500$ in gross annual income and/or have eight or more horses under the Water Quality Improvement Act

315 of 1998 [69]. New Jersey has tiered requirements for developing animal waste management plans, with

316 larger farms (>300 animal units) requiring a Comprehensive Nutrient Management Plan, medium farms (299

317 to 8 animal units) completing a self-certified plan and smaller farms being encouraged, but not required to

318 complete one [60]. Pending regulations for all horse farms across the United States is a significant issue

319 Land Grant University Extension services should be prepared to proactively address through educational

320 programs for horse owners. This could be a major undertaking since the last American Horse Council report

321 indicated there were 9.2 million horses and 1.96 million horse owners in the U.S. [70].

The United States Department of Agriculture Natural Resources Conservation Service (NRCS) is

323 offering an Environmental Quality Incentives Program (EQIP) [71] to help farms in the Chesapeake Bay area

324 improve feed management. By helping farmers formulate their rations more accurately to meet their herd's

325 production requirements, these partners (agencies and universities) are helping farmers decrease the nutrients

326 that are excreted while maintaining or improving livestock production and health. These feeding

327 adjustments can help farmers reduce nitrogen excretions by 30-50\%. The EQIP incentives include payments

328 and provided assistance and cost share help to farms for ration balancing. Both Pennsylvania and New

329 Jersey have begun incentivizing equine operations/managers in these programs.

\subsection{Conclusions}

There are a myriad of factors at play in nitrogen utilization in horses and the impact on the environment. Management of horses and the associated nitrogen inputs and outputs is critical to prevent negative environmental consequences such as decreased air quality and water contamination. Precision feeding and waste management are strategies that can minimize nitrogen excretion and environmental contamination. Feed choices and combinations affect nitrogen availability and absorption in the 
horse. Selection of feeds that are more efficiently utilized by horses, and feeding to meet, but not exceed the

dietary protein and nitrogen requirements of a horse is paramount. This will require an understanding of

339 feed choices and equine digestion, in addition to behavioral modifications in terms of resisting the tendency

340 to feed more than is necessary.

In addition to feeding behavior changes, it is important to develop some sort of integrated decision support systems (DSS) that are more applicable to the needs of horse operations. Karmakar et al [72] reviewed many types of DSS programs and procedures available from academic institutions and industry, yet most of these were intended for or aimed at more traditional livestock operations. Several key decisions

revolve around returning the nutrients to the land to maintain nitrogen balance, yet many horse operations have neither adequate land nor machinery to manage the manure in this manner. An effective DSS guidance tool for equine operators would take into consideration the complexities involved in a livestock business, which often includes managing many animals on an individual basis belonging to individual owners. Additional considerations including potentially high stocking rates, contracted bin removal for manure disposal, and equine business type would need to be incorporated. Finally, calculations and methodology are needed for creating and locating adequate storage, covers or roofing for manure piles, drainage and gutter installation to divert runoff or groundwater around, rather than through, the manure in fields and storage sites.

Because of transportation, storage, and application losses, diet management is an important component of whole farm nitrogen management in keeping water and atmospheric losses at a minimum [51]. Reducing dietary nitrogen has been shown to reduce both ammonia runoff and volatilized nitrogen. Precision feeding can achieve those results without sacrificing production. Further investigation into $\mathrm{CP}$, lysine and other amino acid requirements of horses is also an essential component of moving towards more efficient feeding. Studies detailing the actual requirements of horses at maintenance and various physiological states will enable a movement away from exceeding requirements due to feeding based on predictive regressions. Current legislation in several states incentivizes or requires horse owners to 
362 develop more precise feeding strategies or to manage their farms to reduce potential negative consequences

363 of nitrogen on the environment. Even though related legislation has not yet been enacted in all states, the

364 evidence of the potential environmental implications of horse and other livestock operations should provide

365 horse owners with incentive for incorporating best management practices in feeding and manure

366 management on their farms.

367

368 Acknowledgements

369 This project was supported in part by the US Department of Agriculture Multi-State project NE-1041 and

370 renewal NE-1441, Environmental Impacts of Equine Operations[73]. The authors thank Rozanne McGrath

371 for editorial assistance. 
372 Figure 1: Nitrogen utilization by the horse as adapted from Tanner (2014).

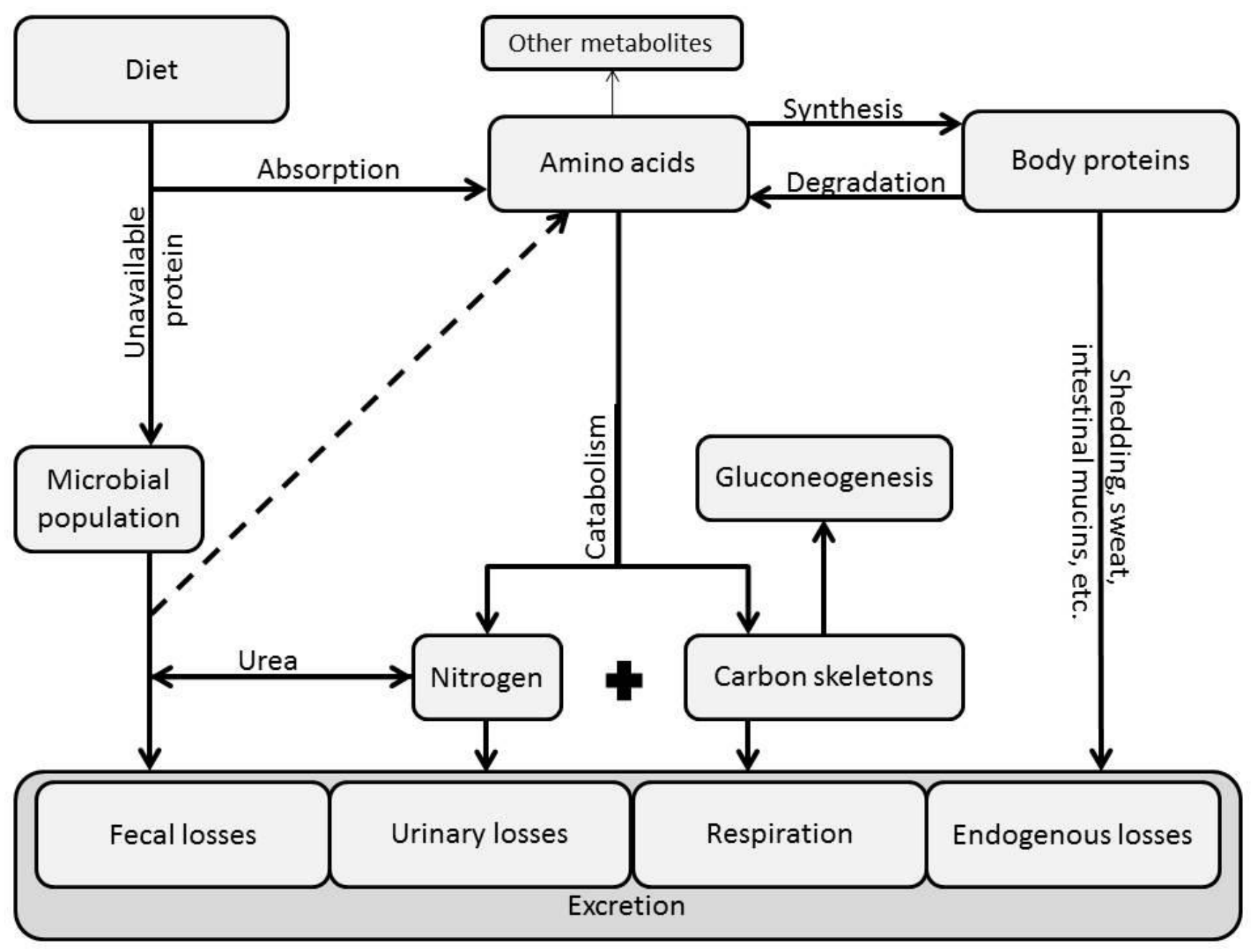

374 The dotted arrow line indicates that the importance and proportion of AA uptake in the hindgut after the

375 digesta has interacted with the largest portion of the microbial population remains largely unknown. 
380 Table 1. Concentrations of ammonia gas $\left(\mathrm{NH}_{3}\right.$ gas), ammonium $\left(\mathrm{NH}_{4}\right)$, total nitrogen $(\mathrm{N})$, nitrate and $\mathrm{pH}$ collected from various 381 studies. Cells with empty (-) values were not tested in a given study.

\begin{tabular}{|c|c|c|c|c|c|c|c|}
\hline $\begin{array}{l}\text { Study } \\
\text { reference }\end{array}$ & $\begin{array}{l}\text { Experimental } \\
\text { Conditions }\end{array}$ & $\begin{array}{l}\text { Bedding or } \\
\text { treatment types }\end{array}$ & $\begin{array}{l}\mathrm{NH}_{3} \text { gas } \\
(\mathbf{p p m})\end{array}$ & $\mathrm{NH}_{4}(\mathrm{ppm})$ & $\begin{array}{l}\text { Total N } \\
\%\end{array}$ & $\begin{array}{l}\text { Nitrate } \\
\text { (ppm) }\end{array}$ & pH \\
\hline \multirow{4}{*}{$\begin{array}{l}\text { Komar et al., } \\
2011 \\
(\text { Mean } \pm \text { SE) }\end{array}$} & \multirow{4}{*}{$\begin{array}{l}\text { Soiled bedding } \\
\text { collected from stalls for } \\
30 \text { days }\end{array}$} & Pelletized Straw & - & $10.1 \pm 2.65$ & $0.71 \pm 0.04$ & 0 & $7.8 \pm 0.1$ \\
\hline & & Long Straw & - & $14.6 \pm 2.65$ & $0.94 \pm 0.04$ & 0 & $8.2 \pm 0.1$ \\
\hline & & Pelletized Wood & - & $13.5 \pm 2.65$ & $0.63 \pm 0.04$ & 0 & $7.7 \pm 0.1$ \\
\hline & & Wood Shavings & - & $17.1 \pm 2.65$ & $0.78 \pm 0.04$ & 0 & $7.9 \pm 0.1$ \\
\hline \multirow{2}{*}{$\begin{array}{l}\text { Williams et } \\
\text { al., } 2011 \\
(\text { Mean } \pm \text { SE) }\end{array}$} & \multirow{2}{*}{$\begin{array}{l}\text { Feces only collected for } \\
5 \text { days from horses on a } \\
\text { low or high protein diet }\end{array}$} & $\begin{array}{l}\text { Feces only low } \\
\text { protein diet }\end{array}$ & $25.4 \pm 3.4$ & $300 \pm 80$ & $0.24 \pm 0.01$ & - & - \\
\hline & & $\begin{array}{l}\text { Feces only high } \\
\text { protein diet }\end{array}$ & $37.8 \pm 3.4$ & $700 \pm 80$ & $0.28 \pm 0.01$ & - & - \\
\hline \multirow{6}{*}{$\begin{array}{l}\text { Fleming et } \\
\text { al., } 2008 \\
(\text { Mean } \pm \text { SD) }\end{array}$} & \multirow{6}{*}{$\begin{array}{l}\text { Feces and urine added } \\
\text { to containers under } \\
\text { standardized conditions } \\
\text { with bedding for } 14 \\
\text { days }\end{array}$} & Wheat Straw & $237 \pm 118$ & $530 \pm 168$ & - & $10 \pm 17$ & - \\
\hline & & Wood Shavings & $207 \pm 116$ & $805 \pm 235$ & - & 0 & - \\
\hline & & Hemp & $193 \pm 114$ & $842 \pm 81$ & - & $162 \pm 58$ & - \\
\hline & & Linen & $178 \pm 88$ & $783 \pm 47$ & - & 0 & - \\
\hline & & Straw Pellets & $80 \pm 51$ & $377 \pm 68$ & - & 0 & - \\
\hline & & Paper Cuttings & $217 \pm 120$ & $843 \pm 54$ & - & 0 & - \\
\hline \multirow{3}{*}{$\begin{array}{l}\text { Garlipp et al., } \\
2011 \\
(\text { Mean } \pm \text { SE) }\end{array}$} & \multirow{3}{*}{$\begin{array}{l}\text { Feces and urea added to } \\
\text { containers with bedding } \\
\text { under standardized } \\
\text { conditions for } 19 \text { days }\end{array}$} & Wheat Straw & $5.75 \pm 0.8$ & - & $1.07 \pm 0.07$ & - & $6.9 \pm 0.11$ \\
\hline & & Rye Straw & $4.07 \pm 0.8$ & - & $1.14 \pm 0.07$ & - & $6.8 \pm 0.11$ \\
\hline & & Wood Shavings & $2.31 \pm 0.8$ & - & $0.61 \pm 0.07$ & - & $6.4 \pm 0.11$ \\
\hline
\end{tabular}


383 Table 2. Concentration range (average) of Crude Protein $(\mathrm{CP})$, Nitrates $\left(\mathrm{NO}_{3}\right)$ and Nitrate-

384 Nitrogen $\left(\mathrm{NO}_{3}-\mathrm{N}\right)$ in common equine feedstuffs. ${ }^{\text {a }}$

\begin{tabular}{|c|c|c|c|c|}
\hline Feedstuff & $\% \mathrm{CP}$ & $\% \mathrm{NO}_{3}$ & ppm $\mathrm{NO}_{3}-\mathrm{N}$ & $\%$ Nitrate \\
\hline \multicolumn{5}{|l|}{ Dry Forage } \\
\hline Legume Hay & $18.6-23.9(21.3)$ & $0.0005-0.35$ & $10.56-788.2$ & $0-0.19$ \\
\hline Grass Hay & $7.0-14.6(10.8)$ & $0-0.69$ & $0-1563$ & $0-0.24$ \\
\hline Bermudagrass & $8.2-13.6(10.9)$ & $0-0.25$ & $0-567.8$ & $0-0.16$ \\
\hline \multicolumn{5}{|l|}{ Hay } \\
\hline Straw & $2.8-7.6(5.2)$ & $0-1.48$ & $0-3341$ & $0-0.04$ \\
\hline Wheat Hay & $6.8-14.3(10.5)$ & $0-0.53$ & $0-1202$ & $0-0.17$ \\
\hline \multicolumn{5}{|l|}{ Fresh Forage } \\
\hline Mixed mostly & $10.9-25.1(18.0)$ & $0-0.23(0.038)$ & $0-511(85.7)$ & $0-.57(0.193)$ \\
\hline \multicolumn{5}{|l|}{ Grass Pasture } \\
\hline Grass Pasture & $7.9-22.8(15.4)$ & $0-0.15(0.052)$ & $0-341(116.4)$ & $0-0.44(0.153)$ \\
\hline \multicolumn{5}{|l|}{ Grains } \\
\hline Barley & $9.6-14.1(11.9)$ & $0.01-0.01(0.01)$ & $22.17-22.17(22.17)$ & $0.003-0.003(0.003)$ \\
\hline Beet Pulp & $7.5-11.1(9.3)$ & $0-0.05(0.022)$ & $0-116.9(48.94)$ & $0.004-0.02(0.012)$ \\
\hline Corn & $7.5-10.6(9.0)$ & 0 & 0 & $0.008-0.008(0.008)$ \\
\hline Oats & $10.5-14.6(12.5)$ & 0 & 0 & $0.02-0.02(0.02)$ \\
\hline Rice Bran & 10.6-18.7 (14.6) & 0 & 0 & 0 \\
\hline Soybean Meal & $46.4-56.0(51.2)$ & $0-0.17(0.004)$ & $0-36.9(9.63)$ & $0.004-0.004(0.004)$ \\
\hline Soybeans & $34.9-44.8(39.9)$ & 0 & 0 & 0 \\
\hline Wheat & $11.0-16.1(13.6)$ & $0-0.01(0.003)$ & $0-28.5(6.60)$ & 0 \\
\hline
\end{tabular}

${ }^{a}$ Data obtained from Equi-Analytical Laboratories, Ithaca, NY, Common Feed Profiles. http://equi-analytical.com/interactive-common-feed-profile/. Accumulated crop years of 2000-

3882014.

\section{References}

391 [1] NRC. Nutrient Requirements of Swine. Washington, D.C.: National Academies Press; 2012. 392 [2] Harper M, Swinker A, Staniar W, Welker A. Ration evaluation of Chesapeake Bay watershed 393 horse farms from a nutrient management perspective. J Equine Vet Sci. 2009;29:401-2. 
[3] Knowlton K, Cobb T. ADSA Foundation Scholar Award: Implementing Waste Solutions for Dairy and Livestock Farms. J Dairy Sci. 2006;89:1372-83

[4] Trottier N, Bott R, Woodward A, Greene E, Williams C, Westendorf M, et al. Evolutionary basis for protein requirement of equids. J Equine Vet Sci. 20xx;xx:xxx-Xxx. [5] Jongbloed A, Lenis N. Environmental concerns about animal manure. J Anim Sci. 1998;76:2641-8.

[6] Frankenberger J, Turco R. Hypoxia in the Gulf of Mexico: A Reason to Improve Nitrogen Management. Purdue Anim Issues Brief AI-6(26 April 2005. 2003.

[7] NOAA. An assessment of coastal hypoxia and eutrophication in U.S. waters. National Science and Technology Council Committee on Environment and Natural Resources. 2003. [8] Sharpley A, Chapra S, Wedepohl R, Sims J, Daniel T, Reddy K. Managing agricultural phosphorus for protection of surface waters: Issues and options. J Environ Qual. 1994;23:437-51. [9] Williams D, Breysse P, McCormack M, Diette G, McKenzie S, Geyh A. Airborne cow allergen, ammonia and particulate matter at homes vary with distance to industrial scale dairy operations: an exposure assessment. Environ Health. 2011;10:72.

[10] Hartung J, Phillips V. Control of gaseous emissions from livestock buildings and manure stores. J Agric Eng Res. 1994;57:173-89.

[11] Komar S, Miskewitz R, Westendorf M, Williams C. Effects of bedding type on compost quality of equine stall waste: Implications for small horse farms. J Anim Sci. 2012;90:1069-75. [12] Krause J. Personal Communication with Jamie L. Kraue, Ag Analytical, Feb 27th, 2015 ed2015.

[13] Whittaker A, Love S, Parkin T, Duz M, Hughes K. Stabling causes a significant increase in the pH of the equine airway. Equine Vet J. 2009;41:940-3. [14] EPA. Environmental Technology Verification (ETV) Program Case Studies:

Demonstrating Program Outcomes. In: Development NRMRLOoRa, editor. Cincinnati, $\mathrm{OH} 2012$.

[15] Greger M, Koneswaran G. The public health impacts of concentrated animal feeding operations on local communities. Family \& Community Health. 2010;33:11-20.

[16] Schiffman S, Studwell C, Landerman L, Berman K, Sundy J. Symptomatic effects of exposure to diluted air sampled from a swine confinement atmosphere on healthy human subjects. Environ Health Perspect. 2005:567-76.

[17] Williams C, Urban C, Westendorf M. Dietary protein affects nitrogen and ammonia excretion in horses. J Equine Vet Sci. 2011;31:305-6.

[18] Katayama Y, Oikawa M, Yoshihara T, Kuwano A, Hobo S. Clinico-Pathological Effects of Atmospheric Ammonia Exposure on Horses. J Equine Sci. 1995;6:99-104.

[19] Tanner M, Swinker A, Beard M, Cosma G, Traub-Dargatz J, Martinez B, et al. Effect of phone book versus sawdust and straw bedding on the presence of airborne gram-negative bacteria, fungi and endotoxin in horse stalls. J Equine Vet Sci. 1998;18:457-61. [20] Pratt S, Lawrence L, Barnes T, Powell D, Warren L. Measurement of ammonia concentrations in horse stalls. J Equine Vet Sci. 2000;20:197-200.

[21] Follett R, Hatfield J. Nitrogen in the environment: sources, problems, and management. Sci World J. 2001;1:920-6. [22] Oenema O, Tamminga S. Nitrogen in global animal production and management options for improving nitrogen use efficiency. Science in China Series C: Life Sciences. 2005;48:871-87. 
[23] Harper M. An assessment of the environmental impact of horse farms in the Chesapeake Baywatershed: Pennsylvania State University; 2010.

441 [24] NRC. Nutrient Requirements of Horses. Washington DC: National Academy Press; 2007.

442 [25] Gallagher J. The potential of pasture to supply the nutritional requirements of grazing

443 horses. Aust Vet J. 1996;73:67-8.

444 [26] Tanner S. Evaluating dietary amino acid adequacy in horses using isotopic techniques

445 [Dissertation]. Lexington, KY: University of Kentucky; 2014.

446 [27] Hintz H, Schryver H, Lowe J. Comparison of a blend of milk products and linseed meal as protein supplements for young growing horses. J Anim Sci. 1971;33:1274-7. [28] Ott E, Asquith R, Feaster J, Martin F. Influence of protein level and quality on the growth and development of yearling foals. J Anim Sci. 1979;49:620-8.

[29] Staniar W, Kronfeld D, Wilson J, Lawrence L, Cooper W, Harris P. Growth of Thoroughbreds fed a low-protein supplement fortified with lysine and threonine. J Anim Sci. 2001;79:2143-51.

[30] Graham-Thiers P, Kronfeld D, Kline K, Sklan D. Dietary protein restriction and fat supplementation diminish the acidogenic effect of exercise during repeated sprints in horses. J Nutr. 2001;131:1959-64.

[31] Kronfeld D. Dietary fat affects heat production and other variables of equine performance, under hot and humid conditions. Equine Vet J Suppl. 1996:24-34.

[32] One D. Feed Composition Libraries. http://dairyone.com/analytical-services/feed-andforage/feed-composition-library2014.

[33] Kolev T, Tahsin N, Koleva L, Ivanov K, Dzhugalov H, Mangova M, et al. Cultivar impact on the chemical content and grain technological qualities of some durum wheat cultivars. J Cent Eur Agric. 2011;12:467-76.

[34] Pagan J. Forages for horses: More than just filler. Adv in Equine Nutr. 1997;1:13-28.

[35] Darlington J, Hershberger T. Effect of forage maturity on digestibility, intake and nutritive value of alfalfa, timothy and orchardgrass by equine. J Anim Sci. 1968;27:1572-6.

[36] Mutz J, Drawe D. Clipping frequency and fertilization influence herbage yields and crude protein content of 4 grasses in South Texas. J Range Manag. 1983:582-5.

[37] Gauer L, Grant C, Bailey L, Gehl D. Effects of nitrogen fertilization on grain protein content, nitrogen uptake, and nitrogen use efficiency of six spring wheat (Triticum aestivum L.) cultivars, in relation to estimated moisture supply. Can J Plant Sci. 1992;72:235-41. [38] Sauberlich H, Chang W, Salmon W. The Amino Acid and Protein Content of Corn as Related to Variety and Nitrogen Fertilization Two Figures. J Nutr. 1953;51:241-50. [39] Garcia L, Perez-Alba L, Alvarez C, Rocha R, Ramos M, de Blas C. Prediction of the nutritive value of Lucerne hay in diets for growing rabbits. Anim Feed Sci and Technol. 1995;54:33-44.

[40] Vanhatalo A, Kuoppala K, Ahvenjarvi S, Rinne M. Effects of feeding grass or red clover silage cut at two maturity stages in dairy cows. 1. Nitrogen metabolism and supply of amino acids. J Dairy Sci. 2009;92:5620-33. [41] Yu P, Rossnagel B, Niu Z. Protein value of a new genotype oat (CDC SO-I) for the NRC dairy model: Protein degradation balance and kinetics, protein fractions and total metabolizable protein supply. Can J Anim Sci. 2008;88:507-13.

[42] Hournard N, Mainville J, Bonin C, Huang S, Luethy M, Malvar T. High-lysine corn generated by endosperm-specific suppression of lysine catabolism using RNAi. Plant Biotechnol J. 2007;5:605-14. 
[43] Huang S, Kruger D, Frizzi A, D'Ordine R, Florida C, Adams W, et al. High-lysine corn produced by the combination of enhanced lysine biosynthesis and reduced zein accumulation. Plant Biotechnol J. 2005;3:555-69. [44] Crawford R, Kennedy W, Johnson W. Some Factors That Affect Nitrate Accumulation in Forages. Agron J. 1961;53:159-62. [45] Wright M, Davison K. Nitrate Accumulation In Crops And Nitrate Poisoning In Animals. In: Norman AG, editor. Advances in Agron: Academic Press; 1964. p. 197-247.

[46] Huntington G. Uptake and transport of nonprotein nitrogen by the ruminant gut. Federation Proc. 1986;45:2272-6.

[47] Godbee R, Slade L. The effect of urea or soybean meal on the growth and protein status of young horses. J Anim Sci. 1981;53:670-6.

[48] Martin R, McMenimann N, Dowsett K. Effects of a protein deficient diet and urea supplementation on lactating mares. J Reprod Fert Suppl. 1991;44:543-50. [49] Schubert R, Zander R, Gruhn K, Hennig A. First results on the incorporation and excretion of $15 \mathrm{~N}$ from orally administered urea in lactating pony mares. Archived Anim Nutr. 1991;41:457-63. [50] Kern D, Slyter L, Leffel E, Weaver J, Oltjen R. Ponies vs. steers: Microbial and chemical characteristics of intestinal ingesta. J Anim Sci. 1974;38:559-64.

[51] Rotz C. Management to reduce nitrogen losses in animal production. J Anim Sci. 2004;82 E-Suppl:E119-37.

[52] Van Horn H, Newton G, Knuckle W. Ruminant nutrition from an environmental perspective. J Anim Sci. 1996;74:3082-102. [53] Koelsch R, Lesoing G. Nutrient balance on Nebraska livestock confinement systems. 1999. [54] Lanyon L, Beegle D. The role of on-farm nutrient balance assessments in an integrated approach to nutrient management. J Soil and Water Conserv. 1989;44:164-8.

[55] Brouwer F. Nitrogen balances at farm level as a tool to monitor effects of agrienvironmental policy. Nutrient Cycl in Agroecosystems. 1998;52:303-8.

[56] Kohn R, Dou Z, Ferguson J, Boston R. A sensitivity analysis of nitrogen losses from dairy farms. J Environ Manag. 1997;50:417-28.

[57] Koelsch R. Evaluating livestock system environmental performance with whole-farm nutrient balance. J Environ Quality. 2005;34:149-55.

[58] Westendorf M, Joshua T, Komar S, Williams C, Govindasamy R. Case study: manure management practices on New Jersey equine farms. Prof Anim Sci. 2010;26:123-9. [59] Westendorf M, Kenny L, Williams C. Protection of environmental resources through the implementation of optimum feed management practices on equine farms. Prof Anim Sci. 2015;31:296-301.

[60] NJDA. Criteria and standards for animal waste management. Chapter 91 Animal Waste Management. New Jersey Register. Volume 41:1171(a). New Jersey Department of Agriculture. Division of Agriculture and Natural Resources. N.J.A.C. 2:91-2.12009. [61] H.35 V. VT H.35: An act relating to improving the quality of State waters. 2015. [62] Bott R, Greene E, Koch K, Martinson K, Siciliano P, Williams C, et al. Production and Environmental Implications of Equine Grazing. J Equine Vet Sci. 2013;33:1031-43.

[63] Swinker A, Worobey S, McKernan H, Meinen R, Kniffen D, Foulk D, et al. Profile of the Equine Industry's Environmental, Best Management Practices and Variations in Pennsylvania. J Equine Vet Sci. 2011;31:334-5. 
530 [64] Swinker A. SARE project, development and implementation of and equine environmental 531 stewardship program, final report. 2013.

532 [65] Privatasky S, Earing J, Lamb J, Sheaffer C, Martinson K. Pasture best management 533 practices on horse farms in Minnesota and Wisconsin. J Equine Vet Sci. 2013;33:398-9. 534 [66] Zeyner A, Kienzle E. A method to estimate digestible energy in horse feed. J Nutr. 535 2002;132:1771S-3S.

536 [67] Mesochina P, Martin-Rosset W, Peyraud J, Duncan P, Micol D, Boulot S. Predication of the 537 digestibility of the diet of horses: evaluation of faecal indices. Grass Forage Sci. 1998;53:189-96. 538 [68] PA. Land application of manure: a supplement to manure management for environmental 539 protection. In: Protection DoE, editor.2011.

540 [69] MD. Clean water action plan technical workgroup. Maryland Clean Water Action Plan: 541 Final 1998 report on Unified Watershed Assessment, Watershed Prioritization and Plans for 542 Restoration Action Strategies. 1998.

543 [70] AHC. National economic impact of the U.S. horse industry.

544 http://www.horsecouncil.org/product/2005-economic-impact-horse-industry-united-states545 national-report 2005.

546 [71] NRCS. MD Environmental quality incentives program. In: USDA, editor.2015. 547 [72] Karmakar S, Lague C, Agnew J, Landry H. Integrated decision support system (DDS) for 548 manure management: A review and perspective. Computers and Electronics in Agric. $549 \quad 2007 ; 57: 190-201$.

550 [73] Westendorf M, Williams C, Burk A, Trottier N, Martinson K, Siciliano P, et al. 551 Environmental impacts of equine operations: a U.S. Department of Agriculture multistate 552 project. J Equine Vet Sci. 2012;32:324-6. 